\title{
Conhecimento teórico da enfermagem sobre parada cardiorrespiratória e ressuscitação cardiopulmonar
}

\author{
Theoretical knowledge of nursing about cardiorrespiratory parade and cardiopulmonary \\ resuscitation
}

\section{Conocimiento teórico de enfermería en la parada cardiorrespiratoria y la reanimación cardiopulmonar}

Dheymi Wilma Ramos Silva ${ }^{1 *}$, Jonas Davi Nogueira Sena ${ }^{1}$, Maria Helena dos Santos Moraes ${ }^{1}$, E'lide Karine Pereira da Silva ${ }^{1}$, Rafael Carvalho de Maria ${ }^{1}$, Aliny De Oliveira Pedrosa ${ }^{1}$, Anderson Araújo Corrêa ${ }^{1}$, Gizelia Araújo Cunha Porto ${ }^{1}$, Jairina Nunes Chaves ${ }^{1}$, Leyla Gerlane De Oliveira Adriano ${ }^{2}$.

\section{RESUMO}

Objetivo: Avaliar o conhecimento dos profissionais de enfermagem sobre parada cardiorrespiratória e ressuscitação cardiopulmonar em uma Unidade de Pronto Atendimento. Métodos: Estudo transversal, de natureza descritivo-exploratória com uma abordagem quantitativa, contou com a participação de 62 profissionais da equipe de enfermagem atuante na Unidade de Pronto Atendimento. A coleta de dados foi realizada através de questionário contendo 18 questões e analisados e realizado dados estatísticos. Resultados: Quanto ao perfil sociodemográfico $88,7 \%$ eram do sexo feminino, 25,8\% tinha de 29 a 33 anos de idade, $27,4 \%$ deles enfermeiros e $72,6 \%$ técnicos de enfermagem, $32,3 \%$ possui de 4 a 6 anos de formado, $82,3 \%$ não possuía especialização profissional assim como $77,4 \%$ não possuía outra formação. Em relação às intervenções baseadas nas diretrizes da American Heart Association os profissionais demonstraram um nível satisfatório de conhecimento. Conclusão: Constatou-se que os profissionais em grande parte possuem conhecimentos básicos para uma boa conduta diante uma parada cardiorrespiratória, contudo em algumas condutas foi possível observar que existem dificuldades e dessa forma é importante que seja promovido ações de capacitação sobre o tema aos profissionais de forma periodica.

Palavras-chave: Parada cardíaca, Reanimação cardiopulmonar, Cuidados de enfermagem.

\begin{abstract}
Objective: To evaluate the nursing professionals' knowledge about cardiorespiratory arrest (CPR) in adults at a Care Unit in the East of Maranhão. Methods: A cross-sectional study, of a descriptive-exploratory nature with a quantitative approach, counted on the participation of 62 professionals of the nursing team working in the Emergency Care Unit. The data collection was performed through a questionnaire containing 18 questions, the data were collected and analyzed in a computer statistical program. Results: Regarding the sociodemographic profile, $88.7 \%$ were female, $25.8 \%$ were 29 to 33 years of age, $27.4 \%$ of them were nurses and $72.6 \%$ were nursing technicians, $32.3 \%$ were 4 at 6 years of training, $82.3 \%$ had no professional specialization and $77.4 \%$ had no other training. For interventions based on the guidelines of the American Heart Association 2015 professionals have demonstrated a satisfactory level of knowledge. Conclusion: It
\end{abstract}

${ }^{1}$ Universidade Estadual do Maranhão, Caxias - MA. *E-mail: dheymiwilma@hotmail.com

${ }^{2}$ Centro Universitário Santo Agostinho, Teresina - PI. 
was verified that the professionals in great part have basic knowledge for a good conduct before a PCR, however in some procedures it was possible to observe that there are difficulties and in this way it is important that training actions on the subject be promoted to the professionals periodically.

Keywords: Cardiac arrest, Cardiopulmonary resuscitation, Nursing care.

\section{RESUMEN}

Objetivo: Evaluar el conocimiento de los profesionales de enfermería sobre el paro cardiorrespiratorio (PCR) en adultos en una Unidad de Cuidados en el Este de Maranhão. Metodos: Un estudio transversal, de carácter descriptivo-exploratorio con enfoque cuantitativo, contó con la participación de 62 profesionales del equipo de enfermería que trabajan en la Unidad de Atención de Emergencias. La recopilación de datos se realizó a través de un cuestionario que contenía 18 preguntas, los datos se recopilaron y analizaron en un programa estadístico informático. Resultados: en cuanto al perfil sociodemográfico, $88.7 \%$ fueron mujeres, $25.8 \%$ tenían entre 29 y 33 años, $27.4 \%$ eran enfermeras y $72.6 \%$ eran técnicos de enfermería, $32.3 \%$ eran 4. a los 6 años de capacitación, el $82.3 \%$ no tenía especialización profesional y el $77.4 \%$ no tenía otra capacitación. Las intervenciones basadas en las directrices de la American Heart Association 2015 han demostrado un nivel de conocimiento satisfactorio. Conclusión: Se verificó que los profesionales en gran parte tienen conocimientos básicos para una buena conducta antes de una PCR, sin embargo, en algunos procedimientos fue posible observar que existen dificultades $y$, por lo tanto, es importante que las acciones de capacitación sobre el tema se promuevan periódicamente a los profesionales.

Palabras clave: Paro cardíaco, Reanimación cardiopulmonar, Cuidados de enfermería.

\section{INTRODUÇÃO}

A parada cardiorrespiratória (PCR) pode ser definida como a ausência da atividade do coração, da circulação e da respiração, que podem ser detectadas pela falta de pulso ou sinais de circulação (SILVA KR, et al., 2017).

Isso ocorre pela perda da função cardíaca devido à falência da atividade ventricular no coração e também a parada respiratória em conjunto, levando o organismo a morte em pouco tempo após a sua ocorrência necessitando assim que aconteça uma intervenção imediata através da ressuscitação cardiorrespiratória (SILVA CCS e HOLANDA AR, 2011).

Os quadros de PCR ainda é um dos principais agravos que resultam em morte em todo o mundo, contudo no Brasil ainda existe um déficit de investimento para levantamentos sobre o número de casos de óbitos por PCR, apesar disso acredita-se que anualmente ocorram aproximadamente 200.000 casos PCRs, no qual por volta da metade desse contingente acontece no meio intra-hospitalar e outra metade em ambiente extra-hospitalar (GONZALEZ MM, et al., 2013).

Em Unidades de Pronto Atendimento ocorrem paradas cardiorrespiratória com frequência devido à instabilidade hemodinâmica acentuada das pessoas, o que torna necessário que a equipe multidisciplinar desenvolva e aprimore os conhecimentos cognitivos, motores, de humanização do atendimento e também a atualização a respeito das manobras de reanimação.

As questões relacionadas à reanimação cardiorrespiratória devem ser de conhecimento de todos os profissionais envolvidos no atendimento e de forma especial da equipe médica e de enfermagem, por serem os responsáveis pela manutenção dos padrões de atendimento e exercício das atividades gerenciais nas instituições de saúde (ZANINI J, et al., 2006).

A realização imediata de ressuscitação cardiopulmonar (RCP) em vítimas de PCR é primordial para sua sobrevivência (KO, et. al. 2018). Ao identificar uma PCR, deve se chamar o paciente pelo nome, avaliar a respiração e o pulso por 10 segundos caso seja detectado ausência de resposta, respiração (ou gasping) e pulso, solicitar um profissional, que, acione a equipe médica, ligando 192 e que traga DEA (desfibrilador 
externo automático) (AHA, 2015). Estas instruções permaneceram recomendadas na atualização da American Heart Assoaciation no ano de 2019, sendo revisada apenas partes especificas da RCP (AHA, 2019).

A Fundação Interamericana do Coração recomenda que os profissionais de saúde recebam constantes treinamentos que enfoquem 0 atendimento a um paciente em PCR e preconiza que estes sejam disseminados de maneira uniforme por meio da padronização de procedimentos e técnicas.

Esta recomendação salienta que os treinamentos melhoram a qualidade do atendimento da vítima em PCR, uma vez que o mesmo será realizado de maneira mais rápida, organizada, calma e efetiva. Além disso, a Fundação orienta sobre a importância da presença de todos os materiais e equipamentos necessários para o atendimento, para que o insucesso da reanimação não seja oriundo da falta de algum desses itens (AHA, 2011).

Em grande número de casos é o enfermeiro, que pertence a equipe de saúde, o primeiro a ter contato com o paciente/cliente em situação de PCR, devendo portanto de estar capacitado para agir e atuar nos acontecimentos que antecedem a PCR, consequentemente sendo útil, na identificação precoce, no atendimento e nos cuidados pós-reanimação do paciente (SILVA AG, 2006).

Em atendimentos de Urgência e Emergência segundo a resolução oํ 423, de 9 de abril de 2012 do Conselho Federal de Enfermagem (COFEN) é assegurado que o enfermeiro tem por uma de suas atribuições estar envolvido na recepção e acolhimento de pacientes realizando sua classificação de risco assim que dão entrada em âmbito hospitalar, dessa forma o profissional deve possuir conhecimento e habilidades suficientes para que se realize uma classificação correta do estado de saúde diminuindo as possibilidades de intercorrências durante o atendimento (COFEN, 2012).

Além dessas características ele precisa ter equilíbrio emocional, o conhecimento teórico-prático, bem como a adequada classificação das funções da equipe por parte destes profissionais, uma vez que, a maior parte da equipe nos atendimentos de RCP é composta por profissionais de enfermagem.

Acima de tudo o enfermeiro necessita transmitir segurança à equipe, atuando de forma objetiva e sincronizada (LUZIA MF e LUCENA AF, 2009). Nesse contexto, objetivou-se avaliar o conhecimento dos profissionais de enfermagem sobre PCR e RCP em adultos em uma Unidade de Pronto Atendimento (UPA) do Leste Maranhense.

\section{MÉTODOS}

Trata-se de um estudo transversal, de natureza descritivo-exploratória com uma abordagem quantitativa realizada no município de Caxias - MA, tendo como população a equipe de enfermagem da UPA da cidade supracitada. A instituição conta com um total de 63 profissionais de enfermagem, sendo 18 enfermeiros e 45 técnicos de enfermagem, destes 1 estava de licença e não foi incluído.

Dessa forma, a amostra total da pesquisa foi composta por um total de 62 participantes que perfazem os profissionais da equipe de enfermagem atuantes no local que concordaram em participar e assinaram 0 termo de consentimento livre e esclarecido.

A coleta de dados foi realizada através de um questionário utilizado por Valentini JS (2014) em sua dissertação apresentada a Sociedade Brasileira de Terapia Intensiva, após adaptação. A coleta aconteceu durante os meses de fevereiro a maio de 2017.

Depois de realizado a coleta foi realizada a revisão dos questionários, onde os dados obtidos foram digitados em banco de dados específico no Microsoft Exceß 2010 e posteriormente analisados no programa SPSS® 22.0 após ser realizada criteriosa revisão com base em comparações dos formulários para correção das possíveis diferenças.

A pesquisa seguiu todos os preceitos da Resolução 466/2012 do Conselho Nacional de Saúde em que inicialmente foi submetido à plataforma Brasil dessa forma sendo encaminhada para avaliação ao Comitê de Ética em Pesquisa e posteriormente aprovada sob parecer ํo 1.96 .848 assim como o Certificado de Apresentação para Apreciação Ética no 63073716.6.0000.5554. 


\section{RESULTADOS}

Os resultados apresentados a seguir mostram o perfil sociodemográfico dos 62 profissionais incluídos na pesquisa, assim como seus conhecimentos sobre parada cardiorrespiratória. Na Tabela 1 é apresentada as características sociodemográficas dos profissionais entrevistados durante a pesquisa. Foi identificado que 0 perfil dos profissionais é composto por $88,7 \%(\mathrm{~N}=55)$ de indivíduos do sexo feminino, com idade média entre 29 e $33(25,8 \%)$ anos.

Tabela 1 - Caracterização dos profissionais de saúde segundo variáveis sociodemográficas. Caxias - MA, $2017(\mathrm{~N}=62)$.

\begin{tabular}{|c|c|c|}
\hline Variáveis & $\mathbf{N}$ & $\%$ \\
\hline \multicolumn{3}{|l|}{ Sexo } \\
\hline Masculino & 7 & 11,3 \\
\hline Feminino & 55 & 88,7 \\
\hline Total & 62 & 100 \\
\hline \multicolumn{3}{|l|}{ Idade (Média = 32,97) e (Desvio Padrão = 6,337) } \\
\hline 18 a 23 & 3 & 4,8 \\
\hline 24 a 28 & 11 & 17,7 \\
\hline 29 a 33 & 16 & 25,8 \\
\hline 34 a 38 & 15 & 24,2 \\
\hline 39 a 43 & 15 & 24,2 \\
\hline Acima de 43 & 2 & 3,3 \\
\hline Total & 62 & 100 \\
\hline \multicolumn{3}{|l|}{ Formação Profissional } \\
\hline Enfermeiro & 17 & 27,4 \\
\hline Técnico de enfermagem & 45 & 72,6 \\
\hline Total & 62 & 100 \\
\hline \multicolumn{3}{|l|}{ Tempo de formação em anos } \\
\hline Menos de um ano & 2 & 3,2 \\
\hline 1 a 3 & 16 & 25,8 \\
\hline 4 a 6 & 20 & 32,3 \\
\hline 7 a 9 & 13 & 21,0 \\
\hline Acima de 9 anos & 11 & 17,7 \\
\hline Total & 62 & 100 \\
\hline \multicolumn{3}{|l|}{ Especialização } \\
\hline Não possui & 51 & 82,3 \\
\hline Não especificou. & 1 & 1,6 \\
\hline Enfermagem em Saúde Pública & 1 & 1,6 \\
\hline Enfermagem em Unidade de Terapia Intensiva & 2 & 3,2 \\
\hline Enfermagem em oncologia & 1 & 1,6 \\
\hline Preceptoria no Sistema Único de Saúde & 1 & 1,6 \\
\hline Saúde do trabalhador & 1 & 1,6 \\
\hline Urgência e Emergência & 4 & 6,4 \\
\hline Total & 62 & 100 \\
\hline \multicolumn{3}{|l|}{ Outra formação } \\
\hline Não possui & 50 & 80,7 \\
\hline Biologia & 1 & 1,6 \\
\hline Pedagogia & 2 & 3,2 \\
\hline Serviço Social & 8 & 12,9 \\
\hline Não especificou & 1 & 1,6 \\
\hline Total & 62 & 100 \\
\hline \multicolumn{3}{|l|}{ Curso de primeiro socorros } \\
\hline Possui & 48 & 77,4 \\
\hline Não possui & 14 & 22,6 \\
\hline Total & 62 & 100 \\
\hline
\end{tabular}

Fonte: Silva DWR, et al., 2017. Adaptado de Valentini JS, 2014. 
No que se refere à formação profissional, a equipe de enfermagem atuante era composta por $72,6 \%$ $(N=45)$ composta por técnicos e $27,4 \%(N=17)$ de enfermeiros. Constatou-se que $82,3 \%(N=51)$ não possuíam nenhuma especialização, dessa forma apenas 11 desses profissionais possuía especialização profissional, onde 6,4\% $(\mathrm{N}=4)$ era na área de urgência e emergência, as demais áreas apresentadas foram em assistência de enfermagem em UTI, técnico em saúde do trabalhador, preceptoria em SUS e enfermagem em oncologia.

Quanto à outra formação profissional $80,7 \%(\mathrm{~N}=50)$ dos entrevistados mencionou não possuir, contudo mais de $15 \%$ dos entrevistados referiram possuir outra formação sendo que nenhuma dessas se relacionava à área da saúde.

Em relação ao treinamento em primeiros socorros $77,4 \%(\mathrm{~N}=48)$ dos entrevistados confirmaram no questionário já terem participado de cursos referentes a primeiros socorros mostrando assim ser uma equipe com conhecimentos sobre os cuidados básicos necessários para intervenção no momento de alguma urgência e emergência.

A Tabela 2 demonstra um comparativo entre algumas das características sociodemográficas que se mostraram predominantes entre os enfermeiros e técnicos de enfermagem. Observa-se que a as duas classes que compõe a equipe de enfermagem atuante na Unidade de Pronto Atendimento estudada, manteve-se equilibrada em suas características sociodemográficas e econômica, no qual $76,5 \%$ dos profissionais enfermeiros $(\mathrm{N}=17)$ pertencem ao sexo feminino, da mesma forma em que a maioria dos profissionais técnicos em enfermagem $(\mathrm{N}=45)$ também são do sexo feminino apresentando $93,3 \%$ dos profissionais.

No quesito ter outra formação profissional as duas classes em grande parte não possuíam sendo para a classe de enfermeiros ( $N=17$ ) $94,1 \%$ dos participantes e para os técnicos ( $N=45) 75,6 \%$. Além disso, observou--se que a grande maioria dos entrevistados não possuíam nenhuma especialização profissional onde dentro da amostra para os técnicos $(\mathrm{N}=45)$ foi mais significativa, perfazendo um total de $93 \%$ da classe que não possuíam nenhuma especialização na área de saúde, já para os enfermeiros $(\mathrm{N}=17)$ teve um total de 52,9\%, o demonstra um certo equilíbrio (Tabela 2).

Tabela 2 - Comparativo entre dados sociodemográficos e econômicos dos enfermeiros e técnicos de enfermagem, Caxias - MA. 2017 ( $N=62)$.

\begin{tabular}{ccccc}
\hline Variáveis & \multicolumn{2}{c}{$\begin{array}{c}\text { Enfermeiro } \\
\text { (N 17) }\end{array}$} & \multicolumn{2}{c}{ Técnicos de Enfermagem } \\
(N 45)
\end{tabular}

Fonte: Silva DWR, et al., 2017. Adaptado de Valentini JS, 2014. 
Referente a participação de treinamentos através de cursos de primeiros-socorros $88,2 \%$ dos enfermeiros afirmaram já terem participado de algum, em comparação a $73,3 \%$ dos técnicos de enfermagem que também confirmaram já ter participado de cursos de primeiros-socorros (Tabela 2).

A Tabela 3 traz resultados referentes ao conhecimento da equipe estudada quanto a dados referentes a classificação inicial da parada cardiorrespiratória assim como as primeiras condutas realizadas por eles.

Tabela 3 - Dados relativos à classificação e atendimento realizado pelos profissionais a vítimas de parada cardiorrespiratória. Caxias - MA, 2017. (N=62).

\begin{tabular}{|c|c|c|}
\hline Variáveis & $\mathbf{N}$ & $\%$ \\
\hline \multicolumn{3}{|l|}{ Situação considerada como caso de urgência } \\
\hline Parada cardiorrespiratória & 20 & 32,3 \\
\hline Desmaios & 23 & 37,1 \\
\hline Queimaduras & 6 & 9,6 \\
\hline Crises convulsivas & 13 & 21,0 \\
\hline Total & 62 & 100 \\
\hline \multicolumn{3}{|l|}{ Situação considera como caso de emergência } \\
\hline Parada Cardiorrespiratória & 56 & 90,3 \\
\hline Crise asmática & 1 & 1,6 \\
\hline Traumatismo Crânio Encefálico Leve & 5 & 8,1 \\
\hline Total & 62 & 100 \\
\hline \multicolumn{3}{|l|}{$\begin{array}{l}\text { Qual sequência de sinais e sintomas devem ser notados para } \\
\text { se iniciar uma Ressuscitação Cardiopulmonar? }\end{array}$} \\
\hline Ausência de pulso; Inconsciência; Respiração normal. & 5 & 8,0 \\
\hline $\begin{array}{c}\text { Inconsciência; Ausência de pulso; Ausência de respiração ou gasp } \\
\text { agônico; }\end{array}$ & 44 & 71,0 \\
\hline Consciência; Respiração normal; Bradicardia. & 13 & 21,0 \\
\hline Total & 62 & 100 \\
\hline \multicolumn{3}{|c|}{ Diante de uma Parada Cardiorrespiratória qual manobra você utilizaria? } \\
\hline Manobra de Ressuscitação Cardiopulmonar & 51 & 82,3 \\
\hline Manobra de liberação de vias aéreas. & 6 & 22,6 \\
\hline Manobra de ventilação. & 5 & 8,1 \\
\hline Total & 62 & 100 \\
\hline \multicolumn{3}{|l|}{$\begin{array}{c}\text { Conduta intra-hospitalar mediante a identificação da Parada } \\
\text { Cardiorrespiratória? }\end{array}$} \\
\hline $\begin{array}{l}\text { Inicia massagem, aciona equipe verbalmente, solicita carro de } \\
\text { PCR; }\end{array}$ & 43 & 69,4 \\
\hline Aciona equipe, inicia ventilação, solicita carro de PCR; & 14 & 22,6 \\
\hline $\begin{array}{l}\text { Inicia ventilação, aciona verbalmente a equipe de enfermagem, } \\
\text { solicita carro de PCR; }\end{array}$ & 5 & 8,1 \\
\hline Total & 62 & 100 \\
\hline
\end{tabular}

Fonte: Silva DWR, et al., 2017. Adaptado de Valentini JS, 2014.

Em ralação a classificação e atendimento, $37,1 \%$ dos profissionais consideraram desmaio como uma urgência, seguido de 32,3\% que optaram por parada cardiorrespiratória, contudo $90,3 \%$ deles também considerou parada cardiorrespiratória como um caso de emergência (Tabela 3). Seguindo assim $71,1 \%$ dos profissionais indicaram que a sequência de sinais a serem observados para se identificar são a inconsciência, ausência de pulso e a ausência de respiração ou gasp agônico (Tabela 3). 
Referente à manobra adequada a ser utilizada durante a parada cardiorrespiratória $82,3 \%(\mathrm{~N}=51)$ dos participantes escolheram a opção da manobra de ressuscitação cardiorrespiratória (RCP). As outras opções que foram marcadas por uma minoria foram às seguintes, liberação de vias aéreas com $9,7 \%$ e a outra manobra de ventilação com 8,0\% (Tabela 3).

Tratando da conduta a ser assumida no atendimento de parada cardiorrespiratória no meio intrahospitalar pela equipe, $69,4 \%$ responderam que se deve iniciar a massagem, acionar verbalmente a equipe e solicitar o carro de parada; $22,6 \%$ marcaram que se deve acionar a equipe, iniciar a ventilação e solicitar carro de parada; e $8,1 \%$ Inicia ventilação, aciona verbalmente a equipe de enfermagem e solicita carro de PCR (Tabela 3).

Na Tabela 4 são encontradas informações relacionadas ao conhecimento dos profissionais sobre as recomendações feitas pela American Heart Association do ano de 2015 sobre as intervenções a serem realizadas durante uma PCR.

Tabela 4 - Conhecimento dos profissionais sobre as diretrizes da American Heart Association (2015) para conduta da RCP. Caxias - MA, 2017. ( $N=62)$

\begin{tabular}{|c|c|c|}
\hline Variáveis & $\mathbf{N}$ & $\%$ \\
\hline \multicolumn{3}{|l|}{$\begin{array}{l}\text { Primeiras medidas a serem tomadas frente a PCR por ordem de } \\
\text { prioridade }\end{array}$} \\
\hline A-B-C* & 18 & 29,0 \\
\hline$C-A-B^{*}$ & 41 & 66,1 \\
\hline$B-A-C^{*}$ & 3 & 4,9 \\
\hline Total & 62 & 100 \\
\hline \multicolumn{3}{|l|}{ Relação de massagem $x$ ventilação em pacientes sem intubação } \\
\hline $15 \times 2$ & 19 & 30,6 \\
\hline $30 \times 2$ & 41 & 66,1 \\
\hline $10 \times 3$ & 2 & 3,3 \\
\hline Total & 62 & 100 \\
\hline \multicolumn{3}{|l|}{ Em relação ao ritmo da massagem, deve ser } \\
\hline $\begin{array}{l}\text { Forte e ritmada, com no mínimo de } 100 \text { e máximo } 120 \text { por minuto } \\
\text { compressões com profundidade do tórax de } 5 \mathrm{~cm} \text {; }\end{array}$ & 50 & 80,6 \\
\hline $\begin{array}{l}\text { Lento e profundo, aproximadamente } 80 / \text { minuto, com profundidade do } \\
\text { tórax de } 4 \text { a } 5 \mathrm{~cm} \text {; }\end{array}$ & 6 & 9,7 \\
\hline $\begin{array}{l}\text { Forte e lento, aproximadamente } 100 / \text { minuto, com profundidade de uma } \\
\text { polegada; }\end{array}$ & 6 & 9,7 \\
\hline Total & 62 & 100 \\
\hline
\end{tabular}

Legenda: *A: Via aérea; B: respiração; C: compressões torácicas.

Fonte: Silva DWR, et al., 2017. Adaptado de Valentini JS, 2014.

Os resultados obtidos quanto as medidas a serem tomadas frente a uma parada por ordem de prioridade $66,1 \%(\mathrm{~N}=41)$ responderam que seria o C-A-B (Circulação; Abrir vias aéreas; Ventilação). Ao serem indagados sobre a relação compressão e ventilação $66,1 \%$ dos profissionais selecionaram que o correto seria de 30 compressões por 2 ventilações.

Espera-se que a massagem cardíaca ou compressões possuam algumas caracteristicas em sua aplicação para serem consideradas de qualidade, referente a isso $80,6 \% \quad(N=50)$ dos participantes selecionaram a opção que conferia que o ritmo das compressões deve ser realizado de maneira forte e ritmado, sendo no mínimo 100 e máximo 120 por minuto com profundidade do tórax de $5 \mathrm{~cm}$ (Tabela 4). Seguindo assim, a Tabela 5 contém informações sobre a utilização do desfibrilador externo automático e também sobre a ventilação após a instalação da via aérea avançada dos pacientes em PCR. 
Tabela 5 - Dados relativos ao conhecimento dos profissionais sobre uso do desfibrilador e ventilação avançada no atendimento à parada cardiorrespiratória. Caxias - MA, 2017. ( $N=62)$

\begin{tabular}{ccc}
\hline Variáveis & $\mathbf{N}$ & $\%$ \\
\hline Em relação ao uso do desfibrilador, os joules aplicados no choque & \\
inicial podem ser: & & \\
\hline $\begin{array}{c}\text { Monofásico 360 Joules ou bifásico 200 Joules } \\
\text { Tanto no monofásico quanto no bifásico deve se iniciar com Joules de }\end{array}$ & 16 & 58,1 \\
100 e ir aumentando gradativamente até 360 Joules & 25,8 \\
Monofásico 100 a 120 Joules e bifásico 360 Joules & 10 & 16,1 \\
Total & 62 & 100 \\
\hline Após via aérea avançada, a ventilação deve ser: & \\
\hline as compressões & 50 & \\
\hline ventilação a cada 6 segundos não necessariamente sincronizadas com & 12 & 19,4 \\
Total 10 ventilações/minuto sincronizado com as compressões & 62 & 100 \\
\hline
\end{tabular}

Fonte: Silva DWR, et al., 2017. Adaptado de Valentini JS, 2014.

Os dados colhidos em relação a utilização do desfibrilador externo automático (DEA) foi de que 58,1\% dos integrantes da pesquisa assinalaram que o correto é que no choque inicial seja feito com uma carga de 360J no desfibrilador externo automático monofásico ou 200 Joules no bifásico.

Quanto a ventilação depois de realizado o procedimento de intubação orotraqueal, 80,6\% afirmaram que deve ser realizada 1 ventilação a cada 6 segundos não necessariamente sincronizada às compressões (Tabela 5). No Gráfico 1 observou-se o conhecimento dos profissionais sobre o medicamento de primeira escolha a ser administrado no paciente durante a parada cardiorrespiratória.

Gráfico 1 - Medicação recomendada durante PCR segundo os profissionais da equipe de enfermagem. Caxias - MA, 2017. ( $N=62)$.

\section{Medicação Recomendada}

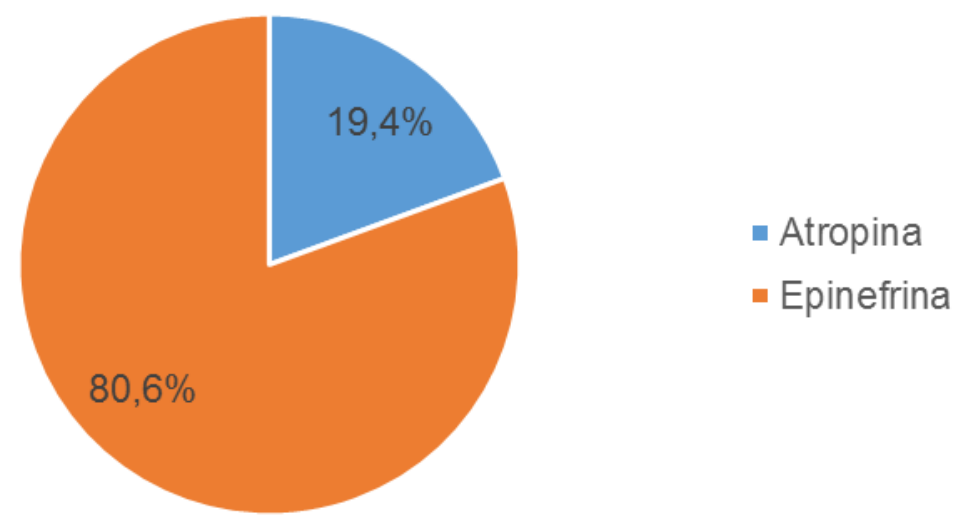

Fonte: Silva DWR, et al., 2017.

Com relação a utilização de medicamentos durante a parada cardiorrespiratória $80,6 \%$ dos profissionais da equipe de enfermagem optaram pela epinefrina ser a mais recomendada durante 0 atendimento aos casos de PCR e 19,4\% selecionaram a atropina (Gráfico 1). 


\section{DISCUSSÃO}

O predomínio do sexo feminino na enfermagem é algo resultante de todo um processo histórico e cultural que envolve a mesma apesar de atualmente existir uma expressividade maior do sexo masculino também atuando na área. Dessa forma como pode ser notado há uma superioridade do sexo feminino a respeito dos profissionais atuantes na Unidade de Pronto Atendimento, corroborando com Machado SA, et al. (2016) onde os mesmos afirmam em sua pesquisa que existe um número superior de mulheres realizando o trabalho de enfermagem do que homens nos campos de trabalho.

Em relação à idade dos profissionais participantes observou-se que a média foi de 32,97 possuindo um desvio padrão de 6,337 sendo assim os profissionais atuantes apresentam-se na faixa etária de jovensadultos. Considera-se que profissionais de enfermagem nessa faixa etária estão mais propensos a busca de melhor qualificação para suas funções, através de especializações sendo essa busca gerada por uma ideia de melhor realizar suas funções além conseguir capacidade para realizar processos que necessitam de maiores habilidades e conhecimentos (MACHADO MH, et. al., 2015).

Como observado no estudo realizado por Almeida AO, et al. (2011) a quantidade de profissionais técnicos de enfermagem compõem a maior parte dos trabalhadores da equipe atuante na Unidade de Pronto Atendimento representando $72,6 \%$ dos profissionais, características essa mantida por inúmeras instituições de saúde em todo o Brasil isso porque o enfermeiro tem como uma de suas atribuições ser o coordenador das atividades realizadas por mais de um técnico no ambiente de trabalho além de também participar diretamente de procedimentos privativos a classe.

Dessa forma outro fato encontrado é que a grande maioria dos profissionais entrevistados não possuía nenhuma especialização ou pós-graduação sendo esses $82,3 \%$ dos entrevistados, dado esse preocupante devido à importância de capacitação profissional para que aconteça um atendimento adequado aos pacientes ademais esse resultado converge com o observado na pesquisa realizada por Ferreira JVB, et al. (2012) em que os profissionais de enfermagem sem especialidade também estavam em maioria.

A busca por mais de uma formação profissional é algo que tem apresentado significativo aumento nos últimos anos em diversas profissões, contudo em relação aos profissionais participantes da pesquisa de forma geral poucos foram o que possuem outra graduação, sendo que a maioria dos que possuem são os da classe de técnicos de enfermagem é importante destacar que os cursos escolhidos pelos trabalhadores não fazem parte do ramo da saúde assim como apresentado por Machado MH, et al. (2016) em que alguns dos cursos mais procurados foram o de Direito, Ed. Física e Pedagogia.

O conhecimento em primeiros-socorros pelos profissionais atuantes na urgência e emergência é crucial para que ocorra uma rápida intervenção dos mesmos sem erros em casos que necessitem, dessa forma é preciso que os enfermeiros e técnicos sejam detentores de conhecimento teórico e prático básico adequado sobre procedimentos a serem utilizados nas emergências sendo essa a primordial ferramenta durante sua jornada de trabalho (CAVALCANTE JL, 2015).

Além do domínio em primeiros-socorros, para um atendimento mais ágil e qualificado no campo da urgência e emergência é necessário que os profissionais disponham de conhecimento sobre como classificar os diferentes casos a que se deparam no seu cotidiano de trabalho. Observa-se que profissionais de enfermagem quando indagados sobre a classificação de alguns casos demonstraram necessidade sobre a classificação correta do tipo de ocorrência a que podem se deparar podendo com isso comprometer suas condutas assim como de toda a equipe já que a classificação de risco correta garante um bom atendimento e segurança ao paciente (JESUS PBR, et al., 2016).

No que diz respeito ao reconhecimento de uma PCR, como o recomendado pela American Heart Association (2015), 71\% dos profissionais selecionaram a opção correta da sequência de avaliação que deve ser executada para se identificar uma parada cardiorrespiratória, no qual a mesma recomenda que seja feita de forma ágil a avaliação do nível de consciência do paciente, seguido da identificação do estado do pulso e respiração do próprio onde esses fatores apresentando-se alterados com inconsciência do paciente, pulso ausente e respiração em gasp ou ausente do mesmo deve-se ser iniciado a RCP de imediato. 
Além de reconhecer a PCR rapidamente, é preciso que os profissionais saibam como intervir agilmente diante uma situação dessas. Ao responderem sobre qual manobra utilizariam na situação citada, a grande maioria respondeu corretamente segundo as recomendações da American Heart Association (2015) sendo a manobra de RCP, assim também quanto a conduta a ser tomada no meio intra-hospitalar sendo elas o início das massagens torácicas, acionamento de toda equipe verbalmente e a solicitação do carro de PCR onde $69,4 \%$ selecionaram a opção que mencionava essas medidas.

Dessa forma o profissional de enfermagem quando é o primeiro a reconhecer e dar suporte ao paciente em parada cardiorrespiratória deve seguir uma sequência de ações sendo elas o início imediato das compressões, liberação das vias aéreas e ventilação do paciente (C-A-B) o conhecimento desse processo otimiza o tempo de resposta do profissional e também as chances de recuperação do paciente (AHA, 2015).

Ao serem questionados sobre a sequência de atendimento os profissionais demonstraram certa dificuldade apesar da maioria apresentarem o conhecimento devido dessa ordem, 66,1\% sendo o mesmo número quanto a relação massagem por ventilação, nota-se que é um contingente apenas um pouco acima da metade assim tornando algo preocupante devido as chances de erro de conduta profissional a respeito dessa sequência de intervenções presente no suporte básico de vida de vida, o que se aproxima dos resultados obtidos por Almeida $A O$, et al. (2011) onde mais da metade do profissionais de enfermagem entrevistados desconheciam a sequência correta recomendada em relação às compressões e ventilação presentes no SBV.

Como percebido as compressões toráxicas são as primeiras medidas a serem tomadas após a identificação de uma PCR, e a American Heart Association (2015) deixa claro que para que uma RCP seja realizada de forma efetiva as compressões devem ser o principal foco de ação dos profissionais sendo ela $e$ a ventilação partes essenciais que compõe a ressussitação cardiorespiratoria, as duas devem assim ser aplicadas seguindo uma associação lógica para que aconteçam de forma correta, essas manobras visam manter artificialmente uma perfusão sanguínea satisfatória para o organismo principalmente a orgãos vitais como o cérebro diminuindo os riscos de lesão nesse tecido assim como o retorno da atividade cardíaca (GOMES JAP e BRAZ MR, 2017).

Os profissionais evidenciaram em sua maioria terem conhecimento a respeito das principais características que deve ter as compressões torácicas durante a RCP esses sendo 80,6\% dos participantes, onde a mesma em sua aplicação deve ser forte e ritmada, com no mínimo de 100 e máximo de 120 compressões por minuto, tendo uma profundidade do tórax de $5 \mathrm{~cm}$ de acordo com o preconizado pela American Heart Association (2015).

Após a chegada da equipe profissional com apoio, faz-se necessário que para maiores chances de recuperação do paciente sejam disponibilizados recursos para uso sendo eles a utilização do Desfibrilador Externo Automático (DEA), a instalação de vias aérea avançada ou mesmo a utilização de da máscara laríngea caso a intubação seja de difícil acesso no paciente, e também administração correta de medicações garantindo uma assistência completa ao paciente podendo assim ser iniciado o Suporte Avançado de Vida (SAV) no qual esse consiste basicamente na manutenção das intervenções iniciais com o tratamento a causa da PCR (ALVES CA, et al., 2013).

Diante isso a equipe de enfermagem deve mostrar domínio no manuseio ou auxílio desses recursos. Em relação a utilização do DEA $58,1 \%$ dos profissionais apresentaram saber como deve ser feito 0 uso do mesmo seguindo as voltagens recomendadas pelos manuais para o choque inicial sendo de $360 \mathrm{~J}$ no DEA monofásico ou $200 \mathrm{~J}$ no bifásico. Esse percentual de acerto aproximou-se do que foi demonstrado por Alves CA, et al. (2013) onde houve apenas 50\% de acertos diante a questão levantada aos profissionais sobre a voltagem a ser utilizada diante uma intervenção a PCR, o que demonstra uma deficiência por parte da equipe de enfermagem atuante na utilização desse recurso.

Continuando, com a instalação da via aérea avançada sendo essa realizada por um profissional qualificado com a assistência da enfermagem, $80,6 \%$ dos profissionais marcaram a opção que corroborava com as recomendações da American Heart Association (2015) referente ao ritmo das ventilações que deveriam ser realizadas sendo 1 ventilação a cada 6 segundos não necessariamente sincronizada às compressões. 
A utilização de medicamentos durante a PCR é de suma importância para a reversão do quadro do paciente, as medicações juntamente a RCP faz com que seja mais facilmente reestabelecida a circulação sanguínea de forma autônoma pelo organismo além de contribuir para a regulação do ritmo cardíaco do paciente sendo assim segundo a American Heart Association (2015) a utilização da epinefrina nos primeiros minutos em que foi instalado o quadro de PCR no paciente está associada com um grande número de casos que tiveram a recuperação da circulação sanguínea espontânea de forma mais rápida sendo essa droga a mais recomendada para a utilização nessas ocasiões.

Assim pode-se observar que $80,6 \%$ dos profissionais da equipe de enfermagem optaram pela epinefrina ser a droga de primeira escolha diante um quando de PCR indo de encontro com o que é recomendado pela American Heart Association (2019), onde fala que a epinefrina seja administrada a pacientes com PCR, onde é razoável administrar $1 \mathrm{mg}$ a cada 3 e 5 minutos.

\section{CONCLUSÃO}

Os dados mostraram que a equipe de enfermagem diante de uma parada cardiorrespiratória possui capacidade e conhecimentos para realizar uma boa conduta. Dessa forma, é importante que seja promovido pela instituição ações de capacitação direcionada a todos os profissionais, com a intenção de minimizar as incertezas dos mesmos e aumentar o poder de ação de toda a equipe de enfermagem aumentando assim a autonomia e qualidade do atendimento prestado por esses profissionais.

\section{REFERÊNCIAS}

1. ALMEIDA AO, et al. Conhecimento teórico dos enfermeiros sobre parada e ressuscitação cardiopulmonar, em unidades não hospitalares de atendimento à urgência e emergência. Rev. Latino-Am. Enfermagem, 2011; 19(2): 261-268.

2. ALVES CA, et al. Parada Cardiorrespiratória e Enfermagem: O Conhecimento Acerca do Suporte Básico De Vida. Cogitare Enferm, 2013; 18(2): 296-301.

3. AMERICAN HEART ASSOCIATION. Destaques das atualizações direcionadas nas diretrizes de 2019 da American Heart Association para RCP e ACE. American Heart Association, AHA, 2019.

4. AMERICAN HEART ASSOCIATION. Destaques das Diretrizes da American Heart Association 2015 para RCP e ACE. American Heart Association, AHA, 2015.

5. AMERICAN HEART ASSOCIATION. SBV para profissionais de saúde. São Paulo: Sesil, 2011.

6. CAVALCANTE JL. Avaliação do nível de conhecimento em primeiros socorros de acadêmicos do curso de Educação Física da UFRN. Monografia (Bacharelado em Educação Física) - Universidade Federal do Rio Grande do Norte, Natal, 2015; 75 p.

7. COFEN. Resolução COFEN n 423/2012. Normatiza, no âmbito do Sistema Cofen/Conselhos Regionais de Enfermagem, a participação do Enfermeiro na atividade de classificação de riscos. Brasília, 2012.

8. FERREIRA JVB, et al. Profile and Theoretical Knowledge of Cardiopulmonary Arrest among Physicians and Nurses in the Rio Branco Municipality, Acre State. Rev Bras Cardiol, 2012; 25(6): 464-70.

9. GOMES JAP, BRAZ MR. Conhecimento de acadêmicos de enfermagem frente à parada cardiorrespiratória. Cadernos UniFOA, 2017; 7(18): 85-91.

10. GONZALEZ MM et al. I Diretriz de Ressuscitação Cardiopulmonar e Cuidados Cardiovasculares de Emergência da Sociedade Brasileira de Cardiologia. Arq. Brasileito de Cardiologia, 2013; 100(2): 105-113.

11. JESUS PBR, et al. Caracterização e classificação de risco em urgência e emergência hipertensiva. Cogitare Enfermagem, 2016; 21(2): 01-09.

12. KO RJM, et al. Easy-to-learn cardiopulmonary resuscitation training programme: a randomised controlled trial on laypeople's resuscitation performance. Singapore Med J, 2018; 59(4): 217-223.

13. LUZIA MF, LUCENA AF. Parada cardiorrespiratória do paciente adulto no âmbito intra-hospitalar: subsídios para a enfermagem. Revista Gaúcha Enfermagem, 2009; 30(2): 328-337.

14. MACHADO MH, et al. Aspectos gerais da formação da enfermagem: o perfil da formação dos enfermeiros técnicos e auxiliares. Enferm. Foco, 2016; 6(2): 15-34.

15. MACHADO MH, et al. Características gerais da enfermagem: o perfil sócio demográfico. Enferm. Foco, 2015; 6(1): $11-17$.

16. MACHADO SA, et al. Avaliação do perfil e qualidade de vida do acadêmico de enfermagem. Rev. Aten. Saúde, 2016; 14(47): 55-60.

17. SILVA AG. Parada Cardiorrespiratória em unidades de internação: vivências do enfermeiro. Dissertação (Mestrado em Enfermagem) - Escola de Enfermagem de Ribeirão Preto. Universidade de São Paulo, Ribeirão Preto, 2006; $192 \mathrm{p}$. 
18. SILVA CCS, HOLANDA AR. Parada Cardiorrespiratória: conhecimento e prática de uma equipe de saúde da família. R Bras Ci Saúde, 2011; 15(4): 447-454.

19. SILVA KR, et al. Parada Cardiorrespiratória e o Suporte Básico de Vida no Ambiente Pré-Hospitalar: Revista O Saber Acadêmico, 2017; 43(1): 53-59.

20. TORRES SFS, et al. A Rede de Urgência e Emergência da Macrorregião Norte de Minas Gerais: um estudo de caso. Saúde Soc, 2015; 24(1): 361-373.

21. VALENTINI JS. Parada cardiorrespiratória no âmbito intra-hospitalar: conhecimento da equipe de enfermagem em um hospital regional. Dissertação (Mestrado Profissionalizante em Terapia Intensiva) - Sociedade Brasileira de Terapia Intensiva, São Paulo, 2014; 89 p.

22. ZANINI J, et al. Parada e reanimação cardiorrespiratória: conhecimentos da equipe de enfermagem em Unidade de Terapia Intensiva. Rev. bras. ter. intensiva, 2006; 18(2): 143-147. 